National and Global Petroleum Assessment

\title{
Assessment of Continuous Gas Resources in the Permian Phosphoria Formation of the Southwestern Wyoming Province, Wyoming, 2019
}

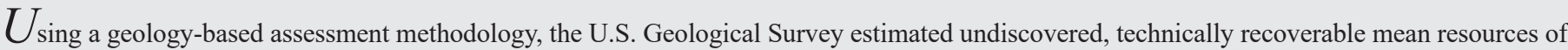 \\ 1.4 trillion cubic feet of continuous gas in the Phosphoria Formation of the Southwestern Wyoming Province, Wyoming.
}

\section{Introduction}

The U.S. Geological Survey (USGS) quantitatively assessed the potential for undiscovered, technically recoverable continuous resources in organic-rich shales of the Permian Phosphoria Formation within the Southwestern Wyoming Province (fig. 1). The Phosphoria Formation represents a complex stratigraphic unit that was deposited in an oceanic embayment along the west-facing Permian continental margin (Sheldon, 1963). During Guadalupian time, cold, nutrient-rich currents from the north swept the embayment, resulting in deposition of phosphatic mudstone, organic-rich shale, and chert in what was otherwise a sediment-starved basin (Piper and Medrano, 1994; Carroll and others, 1998). The deepwater lithologies of the basin transition eastward to shallow-water shelf carbonates of the Permian Park City Formation and finally to continental red mudstone and evaporites of the Permian Goose Egg Formation. Much of the area with the deepwater facies of the Phosphoria Formation is within the Wyoming Thrust Belt Province, but there are deepwater deposits in which the Phosphoria Formation is as much as 10,000 meters (m) deep in the western part of the Southwest Wyoming Province. The purpose of this assessment is to estimate technically recoverable shale-gas resources within Phosphoria Formation shales.

\section{Total Petroleum System and Assessment Unit}

The USGS defined the Phosphoria Total Petroleum System (TPS) and the Phosphoria Shale Gas Assessment Unit (AU) within this TPS. The Phosphoria TPS includes petroleum generated from the organic-rich shales of the Meade Peak and Retort Shale Members of the Permian Phosphoria Formation (Maughan, 1984). Organic-rich shales of the Phosphoria Formation contain marine Type IIS organic matter (Lillis and Selby, 2013) and have total organic carbon content averaging from 4 weight percent to as much as 13 weight percent (Claypool and others, 1978). Organic-rich shales are as much as $60 \mathrm{~m}$ thick for the Meade Peak Member and as much as $30 \mathrm{~m}$ thick for the Retort Member (Maughan, 1984). Phosphoria Formation shales are largely in the dry gas to postmature zone of thermal maturity (Edman and Surdam, 1984; Burtner and Nigrini, 1994). Production tests in several wells along the northern part of the Moxa Arch have shown that the Phosphoria Formation contains gas (Stilwell, 1989), possibly in shales. The assessment input data are summarized in table 1 .

\section{Geologic Model for Assessment}

Mesozoic burial is interpreted to have thermally matured organic-rich shales of the Phosphoria Formation prior to the formation of most Mesozoic Sevier thrust structures in the Wyoming Thrust Belt (Warner, 1982; Burtner and Nigrini, 1994). Much of the Phosphoria oil generated prior to thrust development migrated eastward into structural traps in what are now the Laramide basins in Wyoming, Montana, and Utah (Sheldon, 1967; Lillis and Selby, 2013). Thrust loading to the west placed Phosphoria Formation shales within the thermal window for dry gas or postmature for gas generation (Edman and Surdam, 1984). Following migration, any oil retained within the Phosphoria Formation shales in the Southwestern Wyoming Province would have cracked to gas with progressive burial in the foredeep. Gas within Phosphoria Formation shales may contain high percentages of hydrogen sulfide. In this assessment, the retention of oil in Phosphoria Formation shales following migration and the retention of gas within the shales during burial are the main factors in consideration of geologic uncertainty.

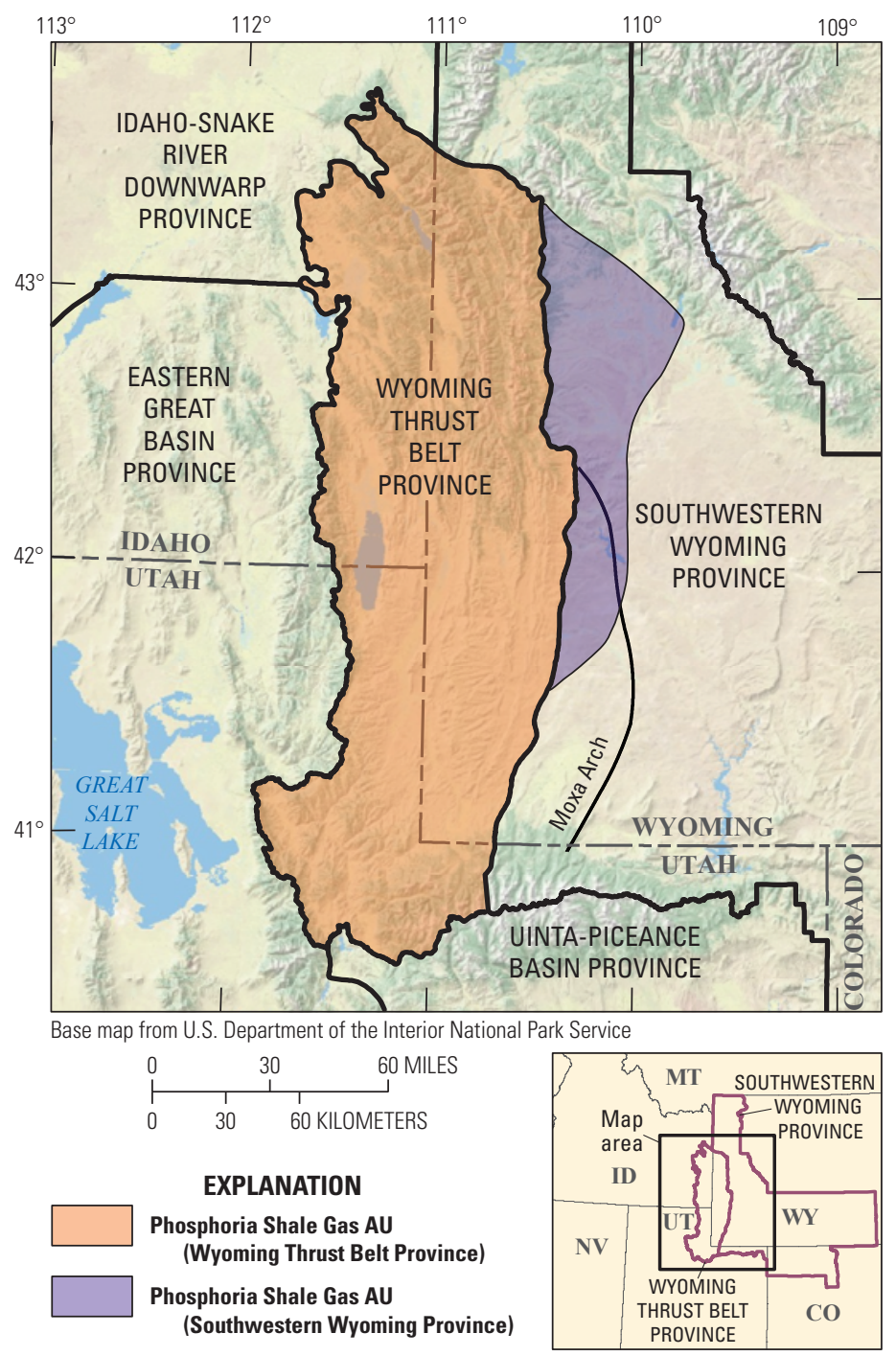

Figure 1. Map showing location of the Phosphoria Shale Gas Assessment Unit (AU) in the Southwestern Wyoming Province, Wyoming. 
Table 1. Input data for one continuous assessment unit in the Phosphoria Formation of the Southwestern Wyoming Province in Wyoming.

[AU, assessment unit; \%, percent; EUR, estimated ultimate recovery per well; BCFG, billion cubic feet of gas. Well drainage area, success ratio, and EUR are defined partly using U.S. shale-gas analogs. The average EUR input is the minimum, median, maximum, and calculated mean. Shading indicates not applicable]

\begin{tabular}{|l|c|c|c|}
\multicolumn{1}{|c|}{$\begin{array}{c}\text { Assessment input data- } \\
\text { Continuous AUs }\end{array}$} & Minimum & Mode & Maximum \\
\cline { 2 - 5 } Calculated mean \\
\hline Potential production area of AU (acres) & 1,000 & 700,000 & $1,433,000$ \\
\hline Average drainage area of wells (acres) & 80 & 120 & 711,333 \\
\hline Success ratio (\%) & 10 & 50 & 160 \\
\hline Average EUR (BCFG) & 0.2 & 0.5 & 90 \\
\hline AU probability & 0.9 & & 120 \\
\hline
\end{tabular}

\section{Undiscovered Resources Summary}

The USGS quantitatively assessed the potential for shale-gas resources within organic-rich shales of the Phosphoria Formation in the Southwestern Wyoming Province (table 2). The estimated mean totals for undiscovered, technically recoverable resources are 1,406 billion cubic feet of gas (BCFG), or 1.4 trillion cubic feet of gas, with an F95-F5 range from 0 to 3,286 BCFG and 6 million barrels of natural gas liquids (MMBNGL) with an F95-F5 range from 0 to 14 MMBNGL. Zeros at the F95 fractiles reflect geologic risk on the retention of gas within shales of the Phosphoria Formation.

Table 2. Results for one continuous assessment unit in the Phosphoria Formation of the Southwestern Wyoming Province in Wyoming.

[BCFG, billion cubic feet of gas; NGL, natural gas liquids; MMBNGL, million barrels of natural gas liquids. Results shown are fully risked estimates. F95 represents a 95-percent chance of at least the amount tabulated; other fractiles are defined similarly. Fractiles are additive under the assumption of perfect positive correlation. Shading indicates not applicable]

\begin{tabular}{|c|c|c|c|c|c|c|c|c|c|c|}
\hline \multirow{3}{*}{$\begin{array}{l}\text { Total petroleum system and } \\
\text { assessment unit (AU) }\end{array}$} & \multirow{3}{*}{$\begin{array}{l}\text { AU prob- } \\
\text { ability }\end{array}$} & \multirow{3}{*}{$\begin{array}{l}\text { Accumu- } \\
\text { lation } \\
\text { type }\end{array}$} & \multicolumn{8}{|c|}{ Total undiscovered resources } \\
\hline & & & \multicolumn{4}{|c|}{ Gas (BCFG) } & \multicolumn{4}{|c|}{ NGL (MMBNGL) } \\
\hline & & & F95 & F50 & F5 & Mean & F95 & F50 & F5 & Mean \\
\hline \multicolumn{11}{|c|}{ Phosphoria Total Petroleum System } \\
\hline Phosphoria Shale Gas AU & 0.9 & Gas & 0 & 1,265 & 3,286 & 1,406 & 0 & 5 & 14 & 6 \\
\hline Total undiscovered continuous resources & & & 0 & 1,265 & 3,286 & 1,406 & 0 & 5 & 14 & 6 \\
\hline
\end{tabular}

\section{References Cited}

Burtner, R.L., and Nigrini, A., 1994, Thermochronology of the IdahoWyoming thrust belt during the Sevier orogeny-A new, calibrated, multiprocess thermal model: American Association of Petroleum Geologists Bulletin, v. 78, no. 10, p. 1586-1612.

Carroll, A.R., Stephens, N.P., Hendrix, M.S., and Glenn, C.R., 1998, Eolian-derived siltstone in the Upper Permian Phosphoria Formation-Implications for marine upwelling: Geology, v. 26, no. 11 , p. $1023-1026$.

Claypool, G.E., Love, A.H., and Maughan, E.K., 1978, Organic geochemistry, incipient metamorphism, and oil generation in black shale members of Phosphoria Formation, western interior United States: American Association of Petroleum Geologists Bulletin, v. 62, no. 1, p. $98-120$

Edman, J.D., and Surdam, R.C., 1984, Influence of overthrusting on maturation of hydrocarbons in Phosphoria Formation, Wyoming-Idaho-Utah Overthrust belt: American Association of Petroleum Geologists Bulletin, v. 68, no. 11, p. 1803-1817.

Lillis, P.G., and Selby, D., 2013, Evaluation of the rhenium-osmium geochronometer in the Phosphoria petroleum system, Bighorn Basin of Wyoming and Montana, USA: Geochimica et Cosmochimica Acta, v. 118, p. 312-330.
Maughan, E.K., 1984, Geological setting and some geochemistry of petroleum source rocks in the Permian Phosphoria Formation, in Woodward, J., Meissner, F.F., and Clayton, J.L., eds., Hydrocarbon source rocks of the greater Rocky Mountain region: Rocky Mountain Association of Geologists, p. 281-294.

Piper, D.Z., and Medrano, M.D., 1994, Geochemistry of the Phosphoria Formation at Montpelier Canyon, Idaho-Environment of deposition: U.S. Geological Survey Bulletin 2023-B, p. B1-B28.

Sheldon, R.P., 1963, Physical stratigraphy and mineral resources of Permian rocks in western Wyoming: U.S Geological Survey Professional Paper 313-B, 273 p.

Sheldon, R.P., 1967, Long-distance migration of oil in Wyoming: Denver, Colo., The Mountain Geologist, v. 4, no. 2, p. 53-65.

Stilwell, D.P., 1989, CO resources of the Moxa Arch and the Madison reservoir, in Eisert, J.L., ed., Gas resources of Wyoming: Casper, Wyo., Wyoming Geological Association, 40th Field Conference Guidebook, p. 105-115.

Warner, M.A., 1982, Source and time of generation of hydrocarbons in the Fossil Basin, western Wyoming Thrust Belt, in Powers, R.B., ed., Geologic studies of the Cordilleran Thrust Belt, volume II: Rocky Mountain Association of Geologists, p. 805-815.

\section{For More Information}

Assessment results are also available at the USGS Energy Resources Program website at https://energy.usgs.gov.

\section{Phosphoria Formation Assessment Team}

Christopher J. Schenk, Tracey J. Mercier, Thomas M. Finn, Kristen R. Marra, Phuong A. Le, Heidi M. Leathers-Miller, Janet K. Pitman, Michael E. Brownfield, and Ronald M. Drake II 